\title{
Pengembangan Multimedia Pembelajaran Interaktif Berpendekatan CTL Pada Pembelajaran Tematik Siswa Kelas IV SD
}

\author{
Komang Hendra Yoga Wijaya Geni \\ Program Studi Teknologi Pendidikan, Universitas Pendidikan Ganesha \\ komang.hendra.yoga@undiksha.ac.id \\ I Komang Sudarma \\ Program Studi Teknologi Pendidikan, Universitas Pendidikan Ganesha \\ ik-sudarma@undiksha.ac.id \\ Luh Putu Putrini Mahadewi \\ Program Studi Teknologi Pendidikan, Universitas Pendidikan Ganesha \\ lpp-mahadewi@undiksha.ac.id
}

\author{
A R T I C L E I N F O \\ Article history: \\ 1 Juli 2020 Received in \\ revised form \\ 30 Agustus 2020 \\ Accepted 28 September 2020 \\ Available online \\ 30 September 2020 \\ Kata Kunci: \\ Multimedia pembelajaran \\ interaktif, kontekstual, ADDIE \\ Keywords: \\ Interactive learning \\ multimedia, contexstual, \\ ADDIE
}

\begin{abstract}
ABSTRAK
Rendahnya hasil belajar siswa pada pembelajaran tematik yang disebabkan karena kurangnya ketersediaan media yang relevan merupakan hal yang melatarbelakangi dari dilaksanakannya penelitian pengembangan ini. Penelitian ini bertujuan untuk mendeskripsikan rancang bangun multimedia pembelajaran interaktif berpendekatan Contexstual Teaching and Learning (CTL), dan untuk mengetahui validitas multimedia pembelajaran interaktif berpendekatan Contexstual Teaching and Learning (CTL). Jenis penelitian ini adalah penelitian pengembangan dengan model pengembangan ADDIE. Jenis data dalam penelitian ini adalah data kuantitatif dan kualitatif. Pengumpulan data penelitian menggunakan metode pencatatan dokumen dan metode kuesioner.
\end{abstract} Teknik analisis data yang digunakan adalah teknik analisis deskriptif kuantitatif, dan deskriptif kualitatif. Hasil penelitian (1) rancang bangun multimedia pembelajaran interaktif berpendekatan kontekstual meliputi 5 tahapan pengembangan yaitu: tahap analisis (analysis), tahap perancangan (design), tahap pengembangan (development), tahap implementasi (implementation), dan tahap evaluasi (evaluation). (2) multimedia pembelajaran interaktif berpendekatan kontekstual dinyatakan valid melalui: (a) review ahli isi pembelajaran memperoleh hasil validitas sangat baik $(97,49 \%)$, (b) review ahli media pembelajaran memperoleh hasil validitas sangat baik $(96,92 \%)$, (c) review ahli desain pembelajaran memperoleh hasil validitas sangat baik $(97,27 \%)$, (d) uji coba perorangan memperoleh hasil validitas sangat baik $(96,11 \%)$, dan (e) uji coba kelompok kecil memperoleh hasil validitas sangat baik $(95,56 \%)$.

\begin{abstract}
The current research background was came from students' low learning outcome in tematik subject. The research objectives were to analyze interactive multimedia learning with the approach of Contextual Teaching and Learning (CTL) and to know the validity of interactive multimedia learning with the approach of Contextual Teaching and Learning (CTL). The research type was development research by using ADDIE research model. Data types in this research were qualitative data and quantitative data. Data were collected through note taking and questionnaire. Data were analyzed quantitatively and qualitatively. The research
\end{abstract}


findings show that (1) there were five steps of interactive multimedia learning with the approach of Contextual Teaching and Learning (CTL) that is, analysis, design, development, implementation, and evaluation. (2) Interactive multimedia learning with the approach of Contextual Teaching and Learning (CTL) was valid based on: (a) experts' review of the content achieved very good score validity (97,49\%), (b) experts' review of the learning media achieved very good score validity(96,92\%), (c) experts' review of the learning design acihieved very good score validity $(97,27 \%),(d)$ individual trials achieved very good score validity (96,11\%), and (e) small group trials achieved very good score validity $(95,56 \%)$.

\section{PENDAHULUAN}

Ilmu pengetahuan dan teknologi (IPTEK) saat ini berkembang begitu pesat sehingga mempengaruhi berbagai aspek kehidupan manusia terutama pada bidang pendidikan. Dunia pendidikan saat ini dituntut untuk selalu dan senantiasa menyesuaikan perkembangan teknologi terhadap usaha dalam peningkatan mutu pendidikan. Berdasarkan hal tersebut, maka sudah seharusnya melakukan perubahan-perubahan pada sistem pendidikan agar dapat menyesuaikan dengan perkembangan yang terjadi saat ini. Salah satu bentuk perubahan sistem pendidikan nasional yang menyesuaikan dengan perkembangan IPTEK saat ini yaitu perubahan kurikulum yang awalnya KTSP menjadi Kurikulum 2013. Pengembangan Kurikulum 2013 merupakan salah satu bentuk pembenahan pendidikan di Indonesia dengan tujuan untuk dapat mengimbangi arus globalisasi (Octaviani, 2017). Salah satu pembelajaran yang telah diterapkan di sekolah dasar yang merupakan gagasan dari kurikulum 2013 yaitu Tematik. Menurut Ananda dan Fadhilaturrahmi (2018) tematik merupakan pembelajaran yang menggabungkan beberapa komponen pada mata pelajaran dan dikemas menjadi satu kesatuan dalam satu tema pembelajaran. Keterlibatan siswa secara aktif dalam mengikuti proses pembelajaran lebih ditekankan pada pembelajaran tematik, sehingga akan memberikan pengalaman langsung dan melatih siswa untuk dapat menemukan sendiri berbagai pengetahuan yang dipelajarinya (Aini dan Relmasira, 2018).

Proses pembelajaran siswa sangat dipengaruhi oleh kualitas yang dimiliki oleh guru. Guru merupakan komponen utama yang memiliki peran sentral dalam mensukseskan pendidikan (Susanto, 2017). Perkembangan IPTEK yang begitu cepat menuntut guru untuk mampu berinovasi dalam proses pembelajaran dan meninggalkan cara lama untuk menuju ke cara baru yang lebih modern dan inovatif dalam kegiatan mengajar melalui pemanfaatan teknologi yang berkembang pesat dizaman sekarang, sehingga proses pembelajaran akan menjadi lebih menarik, memotivasi, dan mampu menciptakan pembelajaran yang lebih berkualitas serta menciptakan lulusan yang berkompetensi dan berdaya saing tinggi (Sole dan Anggraeni, 2018). Namun berbeda dengan kenyataan yang terjadi di lapangan, bahwa saat ini masih banyak guru yang masih menerapkan pembelajaran secara konvensional, dimana metode ceramah dan tanya jawab masih mendominasi dalam kegiatan pembelajaran di kelas, sehingga hal tersebut dapat berdampak terhadap rendahnya motivasi, minat, dan hasil belajar siswa. Hal tersebut dibuktikan melalui hasil observasi lapangan yang telah peneliti lakukan selama kegiatan PPL-Real TP pada semester ganjil tahun akademik 2018/2019 di SD Negeri 1 Paket Agung. Dari hasil observasi tersebut diperoleh informasi bahwa proses pembelajaran yang ada masih bersifat konvensional. Dimana dalam proses pembelajaran guru masih dominan menggunakan metode ceramah dan tanya jawab tanpa ada variasi model lain. Hal ini menjadikan pembelajaran bersifat teacher centered atau berpusat pada guru, sehingga mengakibatkan kejenuhan dan 
menurunkan fokus siswa dalam mengikuti pembelajaran. Selain itu dalam proses pembelajaran, guru terlihat jarang menggunakan media pembelajaran yang inovatif, dimana media yang digunakan hanya sebatas buku paket, LKPD (Lembar Kerja Peserta Didik), dan media-media konvensional yang kurang efektif untuk mendukung materi. Hasil lain yang ditemukan selama kegiatan observasi adalah keaktifan siswa dalam mengikuti proses pembelajaran tematik masih rendah, hal ini dilihat dari $100 \%$ siswa, yang aktif mengikuti pembelajaran hanya $22,58 \%$ saja. Selain itu diperoleh informasi bahwa SD Negeri 1 Paket Agung dilengkapi dengan fasilitas sarana dan prasarana yang memadai dengan kondisi baik untuk mendukung proses pembelajaran, seperti 6 unit LCD (Liquid Crystal Display) proyektor, 6 unit speaker, kepemilikan laptop oleh masing-masing guru, dan sumber kelistrikan yang memadai. Namun fasilitas-fasilitas tersebut belum optimal dimanfaatkan oleh guru untuk menunjang proses pembelajaran.

Hasil observasi tersebut didukung juga dengan hasil wawancara dengan guru wali kelas IV di SD Negeri 1 Paket Agung yang menyatakan bahwa kendala utama yang dihadapi oleh guru dalam mengajar adalah kurangnya media pembelajaran yang dapat mendukung materi pada pembelajaran tematik. Selain itu, konsep materi pada pembelajaran tematik sulit dipahami oleh siswa karena sifat materinya yang cendrung astrak. Informasi lain yang diperoleh yaitu rata-rata hasil belajar siswa kelas IV dengan jumlah siswa sebanyak 31 orang pada pembelajaran tematik terutama pada muatan IPS dan IPA masih belum optimal atau masih dibawah kriteria ketuntasan minumum (KKM). Wawancara juga dilakukan kepada siswa kelas IV SD Negeri 1 Paket Agung yang disertai dengan penyebaran angket analisis karakteristik siswa. Berdasarkan hasil analisis data dari angket karakteristik siswa diperoleh informasi bahwa 80,64\% siswa lebih senang belajar menggunakan media audio visual daripada menggunakan media cetak (LKPD, modul, dll), $77,41 \%$ siswa lebih mudah memahami pelajaran setelah guru menggunakan media pembelajaran, $67,74 \%$ siswa merasa bosan jika kegiatan belajar tidak menggunakan media pembelajaran, dan $83,87 \%$ siswa lebih terbantu memahami materi setelah guru menggunakan media pembelajaran. Berdasarkan hal tersebut, maka strategi yang digunakan oleh guru dalam mengajar selama ini kurang mampu untuk memenuhi prinsip pembelajaran efektif.

Adanya kesenjangan antara kondisi nyata dengan kondisi yang diharapkan, maka jika tidak ditindaklanjuti dikhawatirkan dapat berdampak terhadap rendahnya motivasi, minat, serta hasil belajar siswa itu sendiri. Salah satu alternatif untuk mengurangi pola pembelajaran teacher centered dan pengoptimalan dalam pemanfaatan sarana teknologi yang tersedia adalah guru tidak hanya mengandalkan buku paket dan LKPD saja dalam mengajar, tetapi dapat melengkapi pembelajaran dengan media pembelajaran yang berbasis ICT. Siswa dapat memanfaatkan teknologi dan media untuk meningkatkan kualitas belajarnya (Lestari, 2018). Menurut Wulandari, dkk (2017) pemanfatan sarana teknologi sebagai alat bantu dalam pembelajaran sangat membantu aktivitas proses belajar di kelas, terutama pada peningkatan hasil belajar siswa.

Berdasarkan permasalahan yang telah dipaparkan, maka guru maupun siswa membutuhkan suatu inovasi dalam pembelajaran tematik, terutama inovasi dalam penggunaan media pembelajaran yaitu multimedia pembelajaran interaktif. Multimedia pembelajaran interaktif merupakan salah satu sarana untuk menciptakan pembelajaran yang lebih efektif dalam penyampaian pesan pembelajaran (Firdian dan Maulana, 2018). 
Multimedia pembelajaran interaktif ini dirancang untuk membantu mempermudah siswa dalam proses pembelajaran, dimana dalam proses pembelajaran materi-materi yang disampaikan oleh guru didukung dengan penguatan gambar, suara, video, serta animasi yang terdapat pada multimedia untuk memperjelas materi yang sulit dimengerti oleh siswa. Dengan demikian materi pembelajaran akan menjadi lebih menarik dan mudah dipahami. Sehingga hal tersebut dapat meningkatkan motivasi siswa dalam mengikuti proses pembelajaran yang berujung pada meningkatnya hasil belajar siswa. Disamping itu, dengan media ini juga akan mempermudah guru dalam menyampaikan materi pembelajaran. Hal tersebut sejalan dengan pendapat dari Ivers dan Barron (dalam Sudarma, dkk, 2015) yang menyatakan bahwa multimedia interaktif merupakan sebuah program komputer yang digunakan dalam menyampaikan pembelajaran yang berisikan konten digital dengan kombinasi-kombinasi antara audio, teks, gambar, video serta animasi secara keseluruhan yang terpadu. Melalui gabungan dari komponen-komponen seperti teks, gambar, audio, video, dan animasi yang terpadu, maka multimedia interaktif cocok digunakan untuk memperjelas konsep-konsep yang bersifat abstrak menjadi lebih konkrit (Diyana, dkk, 2019). Dalam multimedia interaktif, materi pembelajaran disampaikan melalui visualisasi statis maupun visualisasi dinamis (animasi), sehingga hal ini dapat menghindari terjadinya verbalisasi yang berlebihan dalam proses pembelajaran (Maria, dkk, 2019). Selain itu multimedia pembelajaran interaktif merupakan media pembelajaran yang memimiliki variasi fitur yang bisa disesuaikan dengan kebutuhan siswa dan dapat mengakomodasi siswa yang memiliki gaya belajar tipe visual, auditif, maupun kinestetik (Prasetya, dkk, 2018).

Penggunaan multimedia pembelajaran interaktif di dalam proses pembelajaran tanpa dibantu dengan model pembelajaran yang tepat tentu tidak akan maksimal hasilnya, karena hal tersebut akan sekedar membuat siswa tertarik saja (Irwanto dan Marliah, 2019). Sehingga dalam penggunaan multimedia interaktif dalam proses pembelajaran harus didukung oleh model ataupun pendekatan pembelajaran yang sesuai. Salah satu pendekatan pembelajaran yang dapat mendukung penggunaan multimedia interaktif dalam proses pembelajaran adalah pendekatan kontekstual (Contextual Teaching and Learning) (Buchori, 2019). Kegiatan belajar mengajar yang menekankan pada pendekatan kontekstual akan membuat siswa senantiasa diajak kedalam lingkungan sehari-hari, karena pengetahuan siswa terbentuk melalui pengetahuan dasar yang sudah dimilikinya. Hal ini sejalan dengan pendapat dari Hobri, dkk (2018) yang menyatakan bahwa Contextual Teaching and Learning (CTL) merupakan pendekatan pembelajaran yang mengkaitkan antara materi yang dipelajari dengan situasi kehidupan nyata siswa, sehingga pengetahuan yang diperoleh siswa menjadi lebih bermakna dan bermanfaat bagi kehidupannya. Hal ini tentu saja dapat membantu siswa dalam menemukan dan menghubungkan materi yang telah dipelajari dengan situasi kehidupan nyata, sehingga dapat mendorong siswa dalam menerapkan apa yang dipelajari pada kehidupan mereka. Penggunaan multimedia interaktif dengan pendekatan kontekstual pada proses pembelajaran dapat mengarahkan siswa untuk memahami materi pembelajaran dengan menghubungkannya pada kehidupan sehari-hari yang didukung dengan pengamatan audio visual dari multimedia (Andrianingrum dan Suparman, 2019).

Penelitian pengembangan ini didukung oleh hasil penelitian yang sudah ada sebelumnya, yaitu hasil penelitian yang dilakukan oleh Kuncahyono dan Sudarmiatin (2018) yang menunjukan bahwa penggunaan multimedia interaktif dalam proses 
pembelajaran dapat menarik perhatian siswa yang berujung pada peningkatan hasil belajar serta dapat membantu dan mempermudah guru dalam menyampaikan materi pembelajaran. Penelitian yang dilakukan oleh Rachmadtullah, dkk (2018) menunjukan bahwa penggunaan multimedia interaktif dalam proses pembelajaran dapat mempermudah siswa dalam belajar, dan efektif untuk meningkatkan motivasi, keaktifan, dan hasil belajar siswa. Penelitian yang dilakukan oleh Widyatmojo dan Muhtadi (2017) menunjukan bahwa pemanfaatan multimedia pembelajaran interaktif dalam proses pembelajaran efektif untuk menstimulasi aspek kognitif dan bahasa siswa. Penelitian yang dilakukan oleh Kusuma, dkk (2018) menunjukan bahwa multimedia pembelajaran interaktif memiliki pengaruh yang signifikan terhadap peningkatan motivasi dan hasil belajar siswa pada pelajaran matematika. Penelitian yang dilakukan oleh Idriani dan Amna (2019) juga menunjukan bahwa penggunaan media pembelajaran berbasis multimedia interaktif efektif untuk meningkatkan keaktifan dan hasil belajara siswa pada pelajaran bahasa inggris. Berdasarkan hasil penelitian tersebut, tentu saja memperkuat bahwa multimedia pembelajaran interaktif sangat bermanfaat dalam proses pembelajaran dan memiliki kemungkinan yang baik pula untuk dikembangkan lebih lanjut dengan subjek penelitian yang berbeda.

Mengacu pada pemaparan diatas, peneliti memandang perlunya media pembelajaran inovatif yang dapat membantu siswa dalam belajar, sehingga diperlukan pengembangan multimedia pembelajaran interaktif berpendekatan kontekstual pada pembelajaran tematik siswa kelas IV di SD Negeri 1 Paket Agung. Multimedia pembelajaran interaktif dipilih karena dapat menjelaskan suatu konsep materi yang bersifat abstrak menjadi lebih konkrit, serta dapat menjadikan pembelajaran lebih menarik, lebih interaktif, dan lebih berkualitas (Surjono, 2017). Oleh karena itu, tujuan penelitian ini adalah: (1) untuk mendeskripsikan rancang bangun multimedia pembelajaran interaktif berpendekatan Contexstual Teaching and Learning (CTL), dan untuk mengetahui validitas multimedia pembelajaran interaktif berpendekatan Contexstual Teaching and Learning (CTL).

\section{METODE PENELITIAN}

Jenis penelitian ini adalah penelitian dan pengembangan atau dikenal dengan research and development $(\mathrm{R} \& \mathrm{D})$. Research and development merupakan metode penelitian ilmiah untuk mengembangkan suatu produk tertentu sekaligus memvalidasi produk tersebut (Sari dan Setiawan, 2018). Penelitian pengembangan ini dilaksanakan pada siswa kelas IV di SD Negeri 1 Paket Agung. Subjek pada penelitian ini yaitu: 2 ahli isi pembelajaran, 1 ahli desain pembelajaran, 1 ahli media pembelajaran, 3 siswa untuk uji coba perorangan, dan 6 siswa untuk uji coba kelompok kecil. Prosedur pengembangan yang digunakan dalam penelitian ini mengacu pada model pengembangan yang digunakan, yaitu model pengembangan ADDIE yang terdiri dari lima tahapan pengembangan yaitu tahap analisis (analysis), tahap perancangan (design), tahap pengembangan (development), tahap implementasi (implementation), dan tahap evaluasi (evaluation). Pemilihan model ADDIE dalam mengembangkan multimedia pembelajaran interaktif ini dikarenakan model ADDIE merupakan model pengembangan yang sederhana namun memiliki tahapan pengembangan yang sistematis, jelas, dan mudah. Selain itu model pengembangan ini memberikan kesempatan kepada pengembang untuk melakukan evaluasi dan revisi scara terus menerus dalam setiap fase yang dilalui. Sehingga produk yang dihasilkan adalah produk yang valid 
dan reliabel. Hal ini sejalan dengan pendapat dari Tegeh, dkk (2014) yang menyatakan bahwa model ADDIE memberi peluang untuk melakukan evaluasi terhadap aktivitas pengembangan pada setiap tahap sehingga diperoleh produk yang berkualitas dan efektif.

Penelitian pengembangan ini menggunakan dua metode pengumpulan data, yaitu : metode pencatatan dokumen dan metode kuesioner. Instrumen yang digunakan untuk mengumpulakan data penelitian pada penelitian pengembangan ini yaitu lembar pencatatan dokumen dan lembar kuesioner. Lembar pencatatan dokumen pada penelitian ini digunakan untuk mengumpulkan dokumen-dokumen terkait dalam perancangan bangun multimedia pembelajaran interaktif dan melakukan pencatatan secara sistematis apabila diperlukan. Hasil dari pencatatan dokumen ini dibentuk berupa laporan pengembangan produk multimedia pembelajaran interaktif secara ringkas. Lembar kuesioner pada penelitian ini digunakan untuk mengukur validitas produk yang dikembangkan dari hasil review ahli isi pembelajaran, ahli media pembelajaran, ahli desain pembelajaran, dan tanggapan siswa saat uji coba perorangan, dan kelompok kecil. Adapun kisi-kisi instrumen kuesioner validitas multimedia pembelajaran interaktif dapat disajikan pada tabel sebagai berikut.

Tabel 1. Kisi-kisi Instrumen Ahli Isi Pembelajaran

\begin{tabular}{|c|c|c|c|}
\hline No & Aspek & Indikator & Jumlah Butir \\
\hline 1 & Struktur Materi & $\begin{array}{l}\text { a. Kompetensi Dasar } \\
\text { b. Indikator } \\
\text { c. Tujuan }\end{array}$ & 3 \\
\hline 2 & Isi Materi & $\begin{array}{l}\text { a. Kejelasan penyajian materi } \\
\text { b. Penggunaan ilustrasi/contoh yang relevan } \\
\text { c. Kesesuaian gambar, animasi dan, video } \\
\text { dengan materi } \\
\text { d. Kelengkapan penyajian materi }\end{array}$ & 5 \\
\hline 3 & Tata Bahas & $\begin{array}{l}\text { a. Penggunaan kalimat yang jelas dan tepat } \\
\text { b. Kesesuaian intonasi kata/kalimat dengan } \\
\text { perkembangan peserta didik }\end{array}$ & 2 \\
\hline 4 & Evaluasi & $\begin{array}{l}\text { a. Kejelasan petunjuk pengerjaan soal } \\
\text { b. Kesesuaian soal dengan materi }\end{array}$ & 2 \\
\hline & & Jumlah & 12 \\
\hline
\end{tabular}

Sumber: (Sanjaya 2015)

Tabel 2. Kisi-kisi Instrumen Ahli Desain Pembelajaran

\begin{tabular}{|c|c|c|c|}
\hline No & Aspek & Indikator & Jumlah Butir \\
\hline 1 & Media & a. Identitas & 2 \\
\hline 2 & Tujuan & $\begin{array}{l}\text { a. Kompetensi Dasar } \\
\text { b. Indikator } \\
\text { c. Tujuan }\end{array}$ & 3 \\
\hline 3 & Strategi & $\begin{array}{l}\text { a. Ketepatan Isi Materi } \\
\text { b. Sistematika Materi } \\
\text { c. Tingkat kemudahan dan kedalaman } \\
\text { materi }\end{array}$ & 7 \\
\hline 4 & Evaluasi & $\begin{array}{l}\text { c. Kejelasan petunjuk pengerjaan soal } \\
\text { d. Kesesuaian soal dengan materi }\end{array}$ & 2 \\
\hline & & Jumlah & 14 \\
\hline
\end{tabular}

Sumber: (Sanjaya 2015) 
Tabel 3. Kisi-kisi Instrumen Ahli Media Pembelajaran

\begin{tabular}{|c|c|c|c|}
\hline No & Aspek & Indikator & Jumlah Butir \\
\hline 1 & $\begin{array}{l}\text { Tampilan } \\
\text { (Desain Pesan) }\end{array}$ & $\begin{array}{l}\text { a. Teks } \\
\text { b. Gambar } \\
\text { c. Audio } \\
\text { d. Video } \\
\text { e. Animasi }\end{array}$ & 20 \\
\hline 2 & Aksesbilitas & $\begin{array}{l}\text { a. Kemudahan Penggunaan } \\
\text { b. Kelancarang Link }\end{array}$ & 2 \\
\hline
\end{tabular}

Sumber: (Sudatha dan Tegeh 2015)

Tabel 4. Kisi-kisi Instrumen Uji Coba Perorangan dan Kelompok Kecil

\begin{tabular}{|c|c|c|c|}
\hline No & Aspek & Indikator & Jumlah Butir \\
\hline 1 & Media & $\begin{array}{l}\text { a. Teks } \\
\text { b. Gambar } \\
\text { c. Video } \\
\text { d. Animasi } \\
\text { e. Audio }\end{array}$ & 5 \\
\hline 2 & Materi & $\begin{array}{l}\text { a. Penggunaan contoh pada media } \\
\text { mempermudah memahami materi } \\
\text { b. Materi pada media mudah di mengerti } \\
\text { c. Materi disajikan sesuai dengan yang } \\
\text { dipelajari disekolah }\end{array}$ & 3 \\
\hline 3 & Strategi & a. Media dapat menarik perhatian siswa & 1 \\
\hline 4 & Evaluasi & $\begin{array}{l}\text { a. Petunjuk pengerjaan soal jelas } \\
\text { b. Soal yang disajikan sesuai dengan materi } \\
\text { yang dipelajari }\end{array}$ & 2 \\
\hline 5 & Manfaat & $\begin{array}{l}\text { a. Penggunaan multimedia mempermudah } \\
\text { proses pembelajaran }\end{array}$ & 1 \\
\hline & & Jumlah & 12 \\
\hline
\end{tabular}

Teknik analisis data yang digunakan pada penelitian pengembangan ini adalah teknik analisis deskriptif kualitatif, dan teknik analisis deskriptif kuantitatif. Menurut Agung (2017), teknik analisis deskriptif kualitatif merupakan teknik analisis data dalam bentuk kalimat atau kata-kata dengan cara menyusun data tersebut secara sistematis sehingga menghasilkan suatu kesimpulan umum. Pada penelitian pengembangan ini, teknik analisis deskriptif kualitatif digunakan untuk mengolah data berupa masukan, komentar, ataupun saran dari para ahli pada uji validitas produk, dan siswa pada uji coba perorangan dan kelompok kecil. Teknik analisis deskriptif kuantitatif merupakan teknik analisis data berupa angka-angka atau persentase dengan cara menyusun data tersebut secara sistematis sehingga menghasilkan suatu kesimpulan umum (Agung, 2017). Pada penelitian pengembangan ini, teknik analisis deskriptif kuantitatif digunakan untuk mengolah data hasil penelitian yang diperoleh melalui angket dalam bentuk skor. Rumus yang digunakan untuk menghitung persentase dari masing-masing subjek adalah sebagai berikut:

$$
\text { Presentase }=\frac{\sum(\text { jawaban } \times \text { bobot tiap pilihan }}{\mathrm{n} \times \text { bobot tertinggi }} \times 100 \%
$$

(Sumber: Tegeh dan Jampel, 2017) 
Keterangan:

$\begin{array}{ll}\sum_{\mathrm{N}} & =\text { Jumlah } \\ & \text { Jumlah seluruh angket }\end{array}$

Selanjutnya, untuk menghitung presentse keseluruhan subyek digunakan rumus:

$$
\text { Presentse }=\mathrm{F}: \mathrm{N}
$$

(Sumber: Tegeh dan Jampel, 2017)

Keterangan:

$\mathrm{F} \quad=$ Jumlah presentase keseluruhn subyek

$\mathrm{N} \quad=$ Banyak subyek

Untuk dapat memberikan makna dalam pengambilan keputusan, maka digunakan ketetapan atau acuan sebagai berikut:

Tabel 5. Konversi Tingkat Pencapaian dengan Skala 5

\begin{tabular}{ccc}
\hline Tingkat Pencapaian & Kualifikasi & Keterangan \\
\hline $90 \%-100 \%$ & Sangat baik & Tidak perlu direvisi \\
$75 \%-89 \%$ & Baik & Sedikit direvisi \\
$65 \%-74 \%$ & Cukup & Direvisi secukupnya \\
$55 \%-64 \%$ & Kurang & Banyak hal yang direvisi \\
$0 \%-54 \%$ & Sangat kurang & Diulangi membuat produk \\
\hline
\end{tabular}

Sumber: (Tegeh dan Jampel, 2017)

\section{HASIL DAN PEMBAHASAN}

Hasil dan pembahasan pada penelitian ini, secara detail dapat dipaparkan sebagai berikut:

\section{HASIL}

Rancang bangun multimedia pembelajaran interaktif ini dikembangkan menggunakan model pengembangan ADDIE yang terdiri dari lima fase atau tahapan pengembangan, yaitu: (1) Tahap pertama yang dilakukan yaitu tahap analisis (analyze). Pada tahap ini dilakukan observasi secara menyeluruh, penyebaran kuesioner kepada siswa dan melakukan wawancara kepada guru kelas sehingga masalah-masalah yang dihadapi oleh guru terkait proses pembelajaran serta hubungan-hubungannya terhadap ketersediaan sarana dan fasilitas pendukung di sekolah atau keterkaitan terhadap karakteristik peserta didik dapat dipecahkan. (2) Tahap kedua yaitu perancangan (design), pada tahap ini dilakukan perancangan media yang akan dikembangkan yaitu meliputi perancangan instrumen penilaian, perancangan RPP, pembuatan flowchart dan storyboard sebagai dasar dan alur yang dipakai pada tahap pengembangan, serta pemilihan software yang digunakan dalam mengembangkan multimedia pembelajaran interaktif. Adapun Software yang digunakan yaitu Articulate Storyline 3 sebagai software utama dan dibantu dengan beberapa aplikasi/software lainnya untuk mendesain gambar, membuat animasi, mengedit video, dan mengedit audio. Aplikasi lainnya yang dimaksud adalah Adobe Flash Professional, Adobe Photoshop, Adobe Primiere, Coreldraw, dan Adobe Audition. (3) Tahap ketiga yaitu pengembangan (development), pada tahap ini kegiatan yang dilakukan yaitu mengembangkan produk berupa multimedia pembelajaran interaktif dari wujud desain menjadi produk yang sesungguhnya sesuai dengan rancangan flowchart dan storyboard dan dikembangkan menggunakan software yang telah ditentukan. (4) Tahap keempat yaitu implementasi (implementation). Pada tahap ini kegiatan yang dilakukan 
yaitu melakukan implementasi media. Implementasi dalam hal ini dimaksudkan untuk menguji validitas produk yang telah dikembangkan. Validasi produk melibatkan review oleh ahli isi pembelajaran, ahli desain pembelajaran, ahli media pembelajaran, uji coba perorangan, dan uji coba kelompok kecil. (5) Tahap terakhir yang dilakukan adalah evaluasi (evaluation). Pada tahap ini dilakukan penilaian terhadap multimedia pembelajaran interaktif yang telah dikembangkan. Pada setiap tahap dalam pengembangan multimedia pembelajaran interaktif ini terdapat evaluasi dan revisi yang dilakukan demi perbaikan produk yang dihasilkan. Penilaian pada evaluasi ini adalah penilaian formatif, yaitu penilaian yang dilaksanakan sepanjang proses pengembangan produk.

Hasil validitas multimedia pembelajaran interaktif ini ditentukan berdasarkan hasil evaluasi oleh (a) ahli isi pembelajaran, (b) ahli desain pembelajaran, (c) ahli media pembelajaran, dan (d) siswa melalui uji coba perorangan dan uji coba kelompok kecil. Data hasil evaluasi dari para ahli dan subjek uji coba produk diolah secara deskriptif dengan mencari prolehan skor rata-rata. Secara lebih rinci, hasil validitas multimedia interaktif dapat disajikan pada tabel sebagai berikut.

Tabel 3. Hasil Uji Validitas Produk

\begin{tabular}{clcl}
\hline No & \multicolumn{1}{c}{ Subjek Uji Coba Multimedia } & $\begin{array}{c}\text { Hasil } \\
\text { Validitas }\end{array}$ & Keterangan \\
\hline 1 & Uji Ahli Isi Pembelajaran & $97,49 \%$ & Sangat Baik \\
2 & Uji Ahli Desain Pembelajaran & $96,92 \%$ & Sangat Baik \\
3 & Uji Ahli Media Pembelajaran & $97,27 \%$ & Sangat Baik \\
4 & Uji Coba Perorangan & $96,11 \%$ & Sangat Baik \\
5 & Uji Coba Kelompok Kecil & $95,56 \%$ & Sangat Baik
\end{tabular}

Melalui hasil uji validitas produk diperoleh masukan, saran, dan komentar yang diberikan oleh para ahli dan subjek uji coba produk. Masukan, saran, dan komentar tersebut selanjutnya dijadikan sebagai dasar atau acuan dalam melakukan perbaikan/revisi produk demi kesempurnaan produk yang dihasilkan. Adapun hasil pengembangan produk multimedia pembelajaran interaktif berpendekatan kontekstual ini, dapat disajikan sebagai berikut.

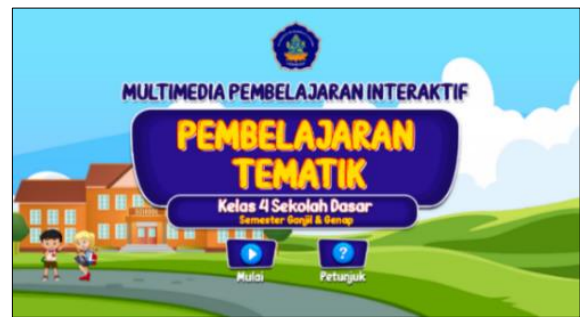

Gambar 2. Halaman Utama Media

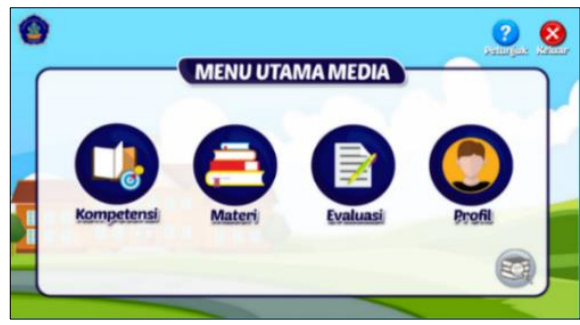

Gambar 4. Halaman Menu Utama

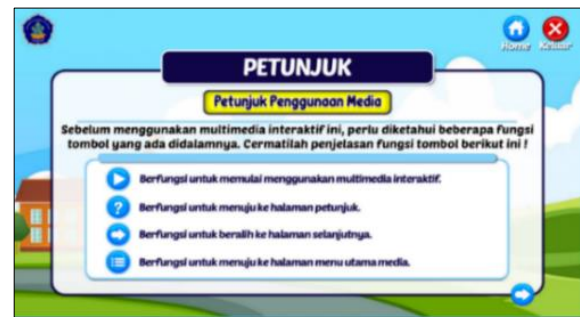

Gambar 3. Halaman Petunjuk

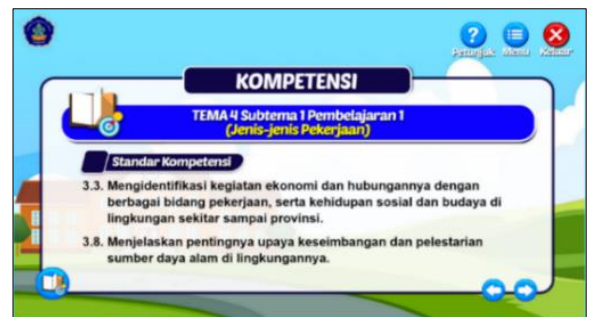

Gambar 5. Halaman Kompetensi 


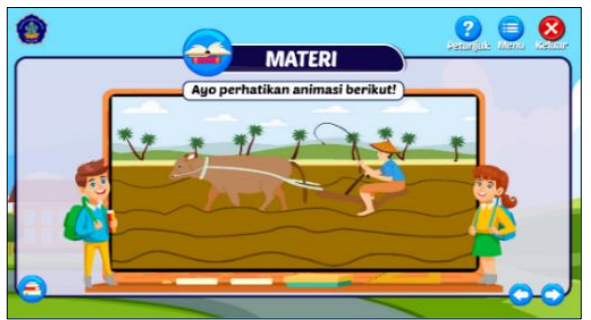

Gambar 6. Halaman Materi

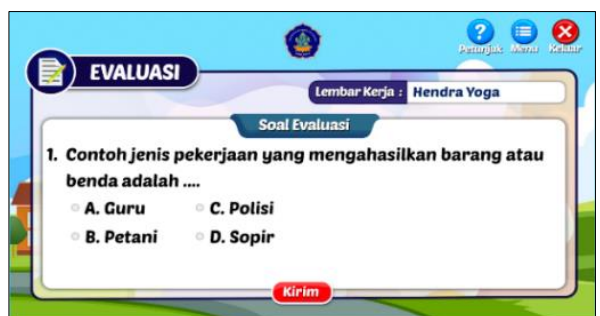

Gambar 7. Halaman Evaluasi

\section{PEMBAHASAN}

Berdasarkan hasil uji validitas produk yang telah dilakukan, multimedia pembelajaran interaktif yang dikembangkan dinyatakan valid dengan kualitas sangat baik dan layak digunakan untuk membantu siswa dalam belajar pada pembelajaran tematik siswa kelas IV di SD Negeri 1 Paket Agung. Hal tersebut dikarenakan multimedia pembelajaran interaktif ini dikembangkan berdasarkan pada hasil analisis kebutuhan, dan dikembangkan dengan model pengembangan yang sistematis serta berpijak pada landasan teoritis. Proses pengembangan multimedia pembelajaran interaktif berpendekatan kontekstual ini mengacu pada model pengembangan ADDIE, sehingga berimplikasi pada kevalidan produk multimedia interaktif yang dihasilkan dan layak untuk digunakan dalam proses pembelajaran. Hal tersebut sesuai dengan hasil penelitian yang dilakukan oleh Kurniawan, dkk (2020) yang menunjukan bahwa pengembangan multimedia pembelajaran interaktif yang mengacu pada model pengembangan ADDIE efektif untuk menciptakan produk yang valid dan layak untuk digunakan dalam proses pembelajaran. Begitu juga dengan hasil penelitian yang dilakukan oleh Fauyan (2019) menunjukan bahwa pengambangan multimedia pembelajaran interaktif dengan menggunakan model pengembangan ADDIE efektif dalam menciptakan produk yang valid dan berkualitas serta layak digunakan untuk menunjang proses pembelajaran siswa.

Konten dan isi pada multimedia pembelajaran interaktif ini dikembangkan dengan mengintegrasikan nilai-nilai pendekatan pembelajaran kontekstual. Pengintegrasian nilainilai kontekstual pada multimedia pembelajaran interaktif ini bertujuan untuk menjadikan pembelajaran menjadi lebih bermakna bagi siswa dan menciptakan suasana pembelajaran yang lebih menyenangkan, karena melalui pembelajaran kontekstual materi pembelajran dikaitkan dengan situasi dunia nyata siswa dan mendorong siswa untuk menghubungkan pengetahuan yang dimiliki dengan penerapannya dalam kehidupan sehari-hari. Hal tersebut sejalan dengan pendapat dari Komalasari (2017) yang menyatakan bahwa pembelajaran kontekstual adalah suatu pendekatan pembelajaran yang mengkaitkan antara materi yang dipelajari dengan kehidupan nyata siswa sehari-hari dengan tujuan untuk menemukan makna dari materi tersebut bagi kehidupannya sehingga berdampak pada peningkatan hasil belajarnya. Pernyataan tersebut juga dibuktikan melalui hasil penelitian yang dilakukan oleh Fadhilaturrahmi (2017) yang menunjukan bahwa penggunaan pendekatan kontekstual dalam pembelajaran efektif meningkatkan keaktifan dan motivasi siswa dalam mengikuti proses pembelajaran, serta efektif untuk meningkatkan hasil belajar siswa. Nilai-nilai pendekatan kontekstual pada multimedia pembelajaran interaktif ini disesuaikan dengan teori Gasong (2018) yang dimodifikasi sesuai dengan kebutuhan. Menurut Gasong (2018) pembelajaran kontekstual melibatkan tujuh komponen utama dalam penerapannya, yakni: konstruktivisme (constructivism), bertanya (questioning), inkuiri/menemukan (inquiry), 
pemodelan (modeling), masyarakat belajar (learning community), refleksi (reflection), dan penilaian yang sebenarnya (authentic assessment).

Berdasarkan pengkajian lebih lanjut, terdapat beberapa aspek penting yang berpengaruh terhadap validitas multimedia interaktif yang dikembangkan. Aspek yang dimaksud yaitu, aspek konten/isi pembelajaran, aspek desain pembelajaran, dan aspek media pembelajaran. Ditinjau dari aspek konten atau isi pembelajaran, multimedia pembelajaran interaktif berpendekatan kontekstual ini berada pada kualifikasi validitas sangat baik. Perolehan kualifikasi validitas sangat baik pada aspek konten/isi pembelajaran dipengaruhi oleh kesesuaian sajian materi dengan rumusan kompetensi dasar, indikator, dan tujuan pembelajaran. Hal ini dibuktikan dari hasil penilaian oleh dua ahli isi pembelajaran pada butir instrumen terkait kesesuaian materi dengan rumusan kompetensi dasar, indikator, dan tujuan pembelajaran memperoleh persentase (100\%) dengan kriteria sangat baik. Begitupula dengan penilaian yang diberikan oleh siswa pada uji coba perorangan dan kelompok kecil terhadap butir instrumen terkait kesesuaian materi memperoleh persentase $(93,33 \%)$ dengan kriteria sangat baik pada uji coba perorangan, dan kriteria sangat baik $(96,67 \%)$ pada uji coba kelompok kecil. Jadi dapat disimpulkan bahwa penyajian materi pada multimedia pembelajaran interaktif ini sudah sesuai dengan tuntutan kompetensi dasar, indikator, dan tujuan pembelajaran yang harus tercapai oleh peserta didik. Hal ini sejalan dengan pendapat dari Chanond, dkk (dalam Sudatha dan Tegeh, 2015:29) yang menyatakan bahwa dalam menilai aspek isi/materi multimedia pembelajaran perlu memperhatikan kesesuaian antara isi materi dengan tujuan pembelajaran yang dituntut tercapai oleh peserta didik, karena elemen tersebut saling berkaitan satu sama lain untuk dapat menciptakan bahan ajar yang baik. Kualifikasi validitas sangat baik pada aspek konten/isi juga diperoleh karena kesesuaian penggunaan visualisasi dalam penyampaian materi pada multimedia pembelajaran interaktif ini. Hal tersebut dibuktikan dari hasil penilaian oleh dua ahli isi pembelajaran pada butir instrumen terkait penggunaan visualisasi pada penyampaian materi memperoleh persentase $(93,75 \%)$ dengan kriteria sangat baik. Begitupula dengan penilaian yang diberikan oleh siswa pada uji coba perorangan dan kelompok kecil terhadap butir instrumen yang berkaitan dengan kesesuaian penggunaan visual untuk memperjelas materi memperoleh persentase $(96,67 \%)$ dengan kriteria sangat baik pada uji coba perorangan, dan kriteria sangat baik $(96,67 \%)$ pada uji coba kelompok kecil. Sehingga dapat disimpulkan bahwa penggunaan visual dalam penyampaian materi pada multimedia pembelajaran interaktif ini sudah sesuai dan dapat memperjelas pesan materi yang disampaikan. Hal ini sejalan dengan pendapat dari Smaldino (dalam Sudarma, dkk, 2015) yang menyatakan bahwa peran visual dalam pembelajaran adalah untuk menekankan informasi yang sifatnya abstrak menjadi lebih konkret, sehingga informasi yang disampaikan menjadi lebih jelas dan mudah untuk dipahami. Pernyataan tersebut juga dibuktikan melalui hasil penelitian yang dilakukan oleh Rosidah (2017) yang menyatakan bahwa peran visual dalam proses pembelajaran efektif untuk memperjelas materi yang disampaikan dan dapat meningkatkan pemahaman konsep siswa, karena melalui tampilan visual, konsep materi yang bersifat abstrak dapat diterjemahkan menjadi lebih konkrit sehingga mudah untuk dipahami.

Ditinjau dari aspek desain pembelajaran, multimedia pembelajaran interaktif berpendekatan kontekstual ini berada pada kualifikasi validitas sangat baik. Perolehan kualifikasi validitas sangat baik dapat tercapai dikarenakan multimedia pembelajaran 
interaktif yang dikembangkan dapat memicu ketertarikan siswa dalam belajar dan dapat mempermudah siswa dalam belajar. Hal ini dibuktikan dari hasil penilaian oleh ahli desain pembelajaran pada butir instrumen terkait penggunaan multimedia yang dapat memicu ketertarikan dan keterlibatan sasaran belajar memperoleh persentase $(100 \%)$ dengan kriteria sangat baik. Begitupula dengan penilaian yang diberikan oleh siswa pada uji coba perorangan dan kelompok kecil terhadap butir instrumen yang berkaitan dengan penggunaan multimedia mempermudah proses pembelajaran memperoleh persentase $(100 \%)$ dengan kriteria sangat baik pada uji coba perorangan, dan kriteria sangat baik $(96,67 \%)$ pada uji coba kelompok kecil. Sehingga dapat disimpulkan bahwa multimedia pembelajaran interaktif yang dikembangkan dapat memicu ketertarikan dan keterlibatan siswa, serta dapat membantu mempermudah siswa dalam belajar. Hal ini sesuai dengan pendapat dari Arsyad (2015) yang menyatakan bahwa penggunaan media pembelajaran dalam kegiatan belajar harus dapat membangkitkan keinginan dan minat yang baru, membangkitkan motivasi, rangsangan belajar, membantu mempermudah proses belajar, dan membawa pengaruh psikologis yang positif terhadap siswa. Pernyataan tersebut juga dibuktikan melalui hasil penelitian yang dilakukan oleh Nursyam, (2019) yang menunjukan bahwa penggunaan media pembelajaran dalam proses pembelajaran dapat meningkatkan minat, ketertarikan, dan keaktifan siswa dalam mengikuti pembelajaran, serta efektif untuk meningkatkan hasil belajar siswa. Kualifikasi validitas sangat baik pada aspek desain pembelajaran juga diperoleh karena kejelasan judul multimedia pembelajaran interaktif dan sasaran pengguna. Hal ini dibuktikan dari hasil penilaian oleh ahli desain pembelajaran pada butir instrumen terkait kejelasan judul media dan sasaran pengguna memperoleh persentase $(93,75 \%)$ dengan kriteria sangat baik. Sehingga dapat disimpulkan bahwa judul dan sasaran pengguna pada multimedia pembelajaran interaktif ini sudah jelas dan sesuai. Judul merupakan komponen penting yang harus ada pada setiap bahan ajar, karena judul adalah identitas utama untuk memberikan gambaran secara umum tentang maksud, arah, dan tujuan dari bahan ajar tersebut, serta untuk memudahkan pengguna dalam memilih bahan ajar yang akan digunakan. Begitu juga dengan sasaran pengguna media yang merupakan sebuah deskripsi singkat yang menginformasikan tentang sasaran pengguna media yang telah ditentukan. Dengan demikian, kejelasan judul dan sasaran pengguna pada bahan ajar dapat memberikan informasi awal kepada pengguna tentang apa yang akan dipelajari secara keseluruhan dari bahan ajar itu sendiri. Hal tersebut sejalan dengan pendapat dari Mahadewi dan Sukmana (2015) yang menyatakan bahwa komponenkomponen dokumen dalam pengembangan suatu produk sangat bervariasi, namun secara standar minimal produk yang dikembangkan harus mengandung kejelasan: judul produk, sasaran dan kebutuhan pengguna, tujuan pembuatan produk, konteks pembuatan produk (profil dan lingkungan pengguna), dan deskripsi produk.

Ditinjau dari aspek media pembelajaran, multimedia pembelajaran interaktif berpendekatan kontekstual ini berada pada kualifikasi validitas sangat baik. Perolehan kualifikasi validitas sangat baik dapat tercapai dikarenakan kesesuaiaan penggunaan elemen-elemen multimedia seperti teks, gambar, suara, video, dan animasi dalam penyampaian pesan pembelajaran. Hal ini dibuktikan dari hasil penilaian oleh ahli media pembelajaran pada butir instrumen terkait kesesuaian penggunaan teks, gambar, suara, video, dan animasi memperoleh persentase $(97,65 \%)$ dengan kriteria sangat baik. Begitupula dengan penilaian yang diberikan oleh siswa pada uji coba perorangan dan kelompok kecil pada butir instrumen yang berkaitan dengan penggunaan teks, gambar, 
suara, video, dan animasi memperoleh persentase $(97,33 \%)$ dengan kriteria sangat baik pada uji coba perorangan, dan kriteria sangat baik $(96,67 \%)$ pada uji coba kelompok kecil. Sehingga dapat disimpulkan bahwa penggunaan teks, gambar, suara, video, dan animasi pada multimedia pembelajaran interaktif ini sudah tepat dan sesuai, serta dapat memperjelas pesan pembelajaran yang disampaikan kepada siswa. Hal ini sesuai dengan pendapat dari Angela dan Cheung (dalam Sudatha dan Tegeh, 2015) yang menyatakan bahwa kesesuaian penggunaan teks, gambar, suara, video, dan animasi sangat penting untuk diperhatikan dalam mengembangkan multimedia pembelajaran agar dapat menghasilkan multimedia pembelajaran yang mampu menarik perhatian dan efekktif dalam penyampaian pesan pembelajaran. Pernyataan tersebut juga dibuktikan melalui hasil penelitian yang dilakukan oleh Pratiwi dan Ismaniati (2017) yang menunjukan bahwa penyampaian materi pembelajaran melalui penggunaan multimedia yang didalamnya terdapat elemen-elemen seperti teks, gambar, suara, video dan animasi yang sesuai dengan materi efektif untuk memperjelas materi yang disampaikan dan dapat meningkatkan minat dan motivasi siswa dalam proses pembelajaran. Kualifikasi validitas sangat baik juga diperoleh karena kemudahan atau kepraktisan penggunaan media. Hal ini dibuktikan dari hasil penilaian oleh ahli media pembelajaran pada butir instrumen terkait kemudahan penggunaan multimedia memperoleh persentase (100\%) dengan kriteria sangat baik. Kemudahan penggunaan pada bahan ajar sangat mempengaruhi niat dan ketertarikan pengguna dalam menggunakan bahan ajar tersebut, karena bahan ajar yang memiliki kemudahan dan kepraktisan dalam pengoperasiaanya secara langsung akan memberikan kenyamanan, daya tarik, dan tidak menimbulkan kebingungan kepada pengguna. Sehingga pengguna akan merasa bermanfaat bagi dirinya dalam menggunakan bahan ajar tersebut. Hal isi sesuai dengan pendapat dari Surjono (2017) yang menyatakan bawa kemudahan penggunaan media pembelajaran secara langsung akan memberikan pengaruh positif terhadap niat dan antusias pengguna dalam menggunakan media pembelajaran serta dapat mempermudah pengguna dalam mengeksplorasi isi dari pada media tersebut. Sejalan dengan hasil penelitian yang dilakukan oleh Hotimah dan Muhtadi (2017) menyatakan bahwa penggunaan multimedia yang dapat dikontrol sesuai dengan kecepatan pemahaman masing-masing siswa memberikan kenyamanan dan daya tarik tersendiri bagi siswa.

\section{SIMPULAN}

Terdapat dua hal yang dapat disimpulkan pada hasil penelitian pengembangan ini, yaitu: (1) rancang bangun multimedia pembelajaran interaktif ini telah dikembangkan melalui beberapa tahapan. Tahapan pengembangan multimedia pembelajaran interaktif ini mengacu pada model pengembangan ADDIE yang terdiri dari lima tahapan pengembangan, yaitu: (a) tahap analisis (analysis), (b) tahap desain (design), (c) tahap pengembangan (development), (d) tahap implementasi (implementation), dan (e) tahap evaluasi (evaluation). (2) Pengembangan multimedia pembelajaran interaktif berpendekatan kontekstual ini mendapat kulifikasi validitas sangat baik yang diperoleh melalui uji ahli isi pembelajaran, uji ahli desain pembelajaran, uji ahli media pembelajaran, uji coba perorangan, dan uji coba kelompok kecil. Sehingga multimedia pembelajaran interaktif berpendekatan kontekstual ini layak digunakan untuk membantu siswa dalam belajar pada pembelajaran tematik siswa kelas IV di SD Negeri 1 Paket Agung. 


\section{DAFTAR PUSTAKA}

Agung, A. A. G. (2017). Metodologi Penelitian Kuantitatif (Prespektif Manajemen Pendidikan). Singaraja: FIP Undiksha.

Aini, Q., dan Relmasira, S. C. (2018). Penerapan Pembelajaran Tematik Integratif Berbasis Kontekstual untuk Meningkatkan Keaktifan dan Hasil Belajar Siswa Kelas 1 SD. Sekolah Dasar: Kajian Teori Dan Praktik Pendidikan, 27(2), 124-132.

Ananda, R., dan Fadhilaturrahmi. (2018). Analisis Kemampuan Guru Sekolah Dasar dalam Implementasi Pembelajaran Tematik di SD. Jurnal Basicedu, 2(2), 11-21.

Andrianingrum, F., dan Suparman. (2019). Design of Interactive Learning Media Based on Contextual Approach to Improve Problem- Solving Ability in Fourth Grade Students. International Journal of Scientific \& Technology Research, 8(11), 3906-3911.

Arsyad, A. (2015). Media Pembelajaran. Jakarta: Raja Grafindo Persada.

Buchori, A. (2019). Pengembangan Multimedia Interaktif dengan Pendekatan Kontekstual untuk Meningkatkan Pemecahan Masalah Kemampuan Matematika. Jurnal Inovasi Teknologi Pendidikan, 6(1), 104-115.

Diyana, T. N., dkk. (2019). Pengembangan Multimedia Interaktif Topik Prinsip Archimedes untuk Mengoptimalkan Student Centered Learning. Jurnal Inovasi Teknologi Pendidikan, 6(2), 171-182.

Fadhilaturrahmi. (2017). Peningkatan Hasil Belajar Siswa Pada Materi Jaring-Jaring Balok dan Kubus dengan Pendekatan Contextual Teaching and Learning (CTL) Siswa Kelas IV SDN 05 Air Tawar Barat. Jurnal Basicedu, 1(1), 1-9.

Fauyan, M. (2019). Developing Interactive Multimedia Through Ispring on Indonesian Language Learning with The Insights of Islamic Values in Madrasah Ibtidaiyah. Al Ibtida: Jurnal Pendidikan Guru MI, 6(2), 177-190.

Firdian, F., dan Maulana, I. T. (2018). Pengembangan Media Pembelajaran Multimedia Interaktif pada Matakuliah Aplikasi Software. Jurnal Pendidikan: Teori, Penelitian Dan Pengembangan, 3(6), 822-828.

Gasong, D. (2018). Belajar dan Pembelajaran. Yogyakarta: Deepublish.

Hobri., dkk. (2018). High-Order Thinking Skill in Contextual Teaching and Learning of Mathematics Based on Lesson Study for Learning Community. International Journal of Engineering \& Technology, 7(3), 1576-1580.

Hotimah, dan Muhtadi, A. (2017). Pengembangan Multimedia Pembelajaran Interaktif IPA untuk Meningkatkan Pemahaman Siswa pada Materi Mikroorganisme SMP. Jurnal Inovasi Teknologi Pendidikan, 4(2), 201-213.

Idriani, S., dan Amna, S. (2019). Designing a Learning Media of English for Specific Purpose Based on Interactive Multimedia (Macromedia Flash 0.8) for Agro-Industry Students. Jurnal Arbitrer, 6(2), 137-146.

Irwanto, dan Marliah. (2019). Penggunaan Pendekatan Contextual Teaching Learning Berbasis Multimedia Interaktif untuk Meningkatkan Motivasi dan Hasil Belajar Siswa pada Mata Pelajaran IPA. Jurnal Taman Cendekia, 3(2), 342-349.

Kuncahyono, dan Sudarmiatin. (2018). Pengembangan Multimedia Interaktif pada Pembelajaran Tematik Indahnya Negeriku untuk Siswa Kelas IV Sekolah Dasar. Ilmu Pendidikan: Jurnal Kajian Teori Dan Praktik Kependidikan, 3(2), 156-163. 
Kurniawan, F. Y., dkk. (2020). Pengembangan Multimedia Interaktif Berbasis Adventure Game pada Materi Prinsip Animasi. Jurnal Inovasi Teknologi Pendidikan, 6(2), 183195.

Kusuma, R., dkk. (2018). Multimedia Pembelajaran Matematika Interaktif Berbasis Komputer. Desimal: Jurnal Matematika, 1(2), 191-199.

Lestari, S. (2018). Peran Teknologi dalam Pendidikan di Era Globalisasi. Edureligia; Jurnal Pendidikan Agama Islam, 2(2), 94-100.

Mahadewi, L. P. P., dan Sukmana, A. I. W. I. Y. (2015). Text-Based Programming: Konsep Dasar \& Aplikasi Pengembangan Produk Pendidikan. Yogyakarta: Graha Ilmu.

Maria, U., dkk. (2019). Interactive Multimedia Development in The Learning Process of Indonesian Culture Introduction Theme for 5-6 Year Old Children. Journal of Primary Education, 8(3), 344-353.

Nursyam, A. (2019). Peningkatan Minat Belajar Siswa Melalui Media Pembelajaran Berbasis Teknologi Informasi. Ekspose: Jurnal Penelitian Hukum Dan Pendidikan, 18(1), 811-819.

Octaviani, S. (2017). Pengembangan Bahan Ajar Tematik Dalam Implementasi Kurikulum 2013 Kelas 1 Sekolah Dasar. EduHumaniora: Jurnal Pendidikan Dasar, 9(2), 93-98.

Prasetya, A. Y. W. N., dkk. (2018). Multimedia Interaktif pada Pembelajaran Tematik untuk Kelas IV Sekolah Dasar. Jurnal Pendidikan: Teori, Penelitian, dan Pengembangan, 3(11), 1423-1427.

Pratiwi, H. R., dan Ismaniati, C. (2017). Pengembangan Multimedia Pembelajaran untuk Mengembangkan Aspek Kognitif Anak. Jurnal Inovasi Teknologi Pendidikan, 4(2), $130-139$.

Rachmadtullah, R., dkk. (2018). Development of Computer-Based Interactive Multimedia : Study on Learning in Elementary Education. International Journal of Engineering \& Technology, 7(4), 2035-2038.

Rosidah, A. (2017). Penerapan Media Pembelajaran Visual untuk Meningkatkan Pemahaman Konsep Siswa pada Mata Pelajaran IPS. Jurnal Cakrawala Pendas, 2(2), $121-126$.

Sari, P. A., dan Setiawan, A. (2018). The Development of Internet-Based Economic Learning Media using Moodle Approach. International Journal of Active Learning, 3(2), 100-109.

Sole, F. B., dan Anggraeni, D. M. (2018). Inovasi Pembelajaran Elektronik dan Tantangan Guru Abad 21. Jurnal Penelitian Dan Pengkajian Ilmu Pendidikan: E-Saintika, 2(1), $10-18$.

Suartama, I. K. (2016). Evaluasi dan Kriteria Kualitas Multimedia Pembelajaran. Singaraja: FIP Undiksha.

Sudarma, I. K., dkk. (2015). Desain Pesan Kajian Analitis Desain Visual Teks dan Image. Yogyakarta: Graha Ilmu.

Sudatha, I. G. W., dan Tegeh, I. M. (2015). Desain Multimedia Pembelajaran. Yogyakarta: Media Akademi.

Surjono, D. H. (2017). Multimedia Pembelajaran Interaktif Konsep dan Pengembangan. 


\section{Yogyakarta: UNY Prees.}

Susanto, A. (2017). Manajemen Peningkatan Kinerja Guru (Konsep, Strategi, dan Implementasi). Jakarta: Pernada Media Group.

Tegeh, I. M., dan Jampel, I. N. (2017). Metode Penelitian Pengembangan. Singaraja: Undiksha.

Tegeh, I. M., dkk. (2014). Model Penelitian Pengembangan. Yogyakarta: Graha Ilmu.

Widyatmojo, G., dan Muhtadi, A. (2017). Pengembangan Multimedia Pembelajaran Interaktif Berbentuk Game untuk Menstimulasi Aspek Kognitif dan Bahasa Anak TK. Jurnal Inovasi Teknologi Pendidikan, 4(1), 38-49.

Wulandari, R., dkk. (2017). Penggunaan Multimedia Interaktif Bermuatan Game Edukasi untuk Meningkatkan Aktifitas dan Hasil Belajar Siswa Sekolah Dasar. Jurnal Pendidikan: Teori, Penelitian, dan Pengembangan, 2(8), 1024-1029. 